\title{
GENDER DIFFERENCIES IN PERCEPTION QUALITY OF RURAL TOURIST DESTINATION
}

\author{
[Genderové rozdíly ve vnímání kvality venkovské destinace cestovního ruchu]
}

\author{
Astrida Peruthová ${ }^{1}$, Kateřina Ryglová ${ }^{2}$ \\ ${ }^{1}$ Mendelova univerzita v Brně, Provozně ekonomická fakulta, Zemědělská 5, 61300 Brno \\ Email: astrida.peruthova@mendelu.cz \\ ${ }^{2}$ Mendelova univerzita v Brně, Provozně ekonomická fakulta, Zemědělská 5, 61300 Brno \\ Email: katerina.ryglova@mendelu.cz
}

\begin{abstract}
The goal of this paper is to find differencies between men and women perception quality in rural tourits'destinations in the Czech Republic. Respondents were residents from the Czech Republic. Data was collected by paper and electronic questionaire in 2016. Number of respondents was $660-330$ men and 330 women. Kruskal - Wallis test was uesd for evaluation data. 23 factors of destination quality were evaluated. The most important factor was sence of security, cleanliness of the destination and natural attractivities for both genders. The perception of the 10 quality factors were gender-specific. This research can help in creating a destination marketing communications.
\end{abstract}

Keywords: destination quality factors, gender, rural destination, tourism.

JEL classification: L83, Z32

Doručeno redakci: 5.12.2017; Recenzováno: 31.1.2018; 1.2.2018; Schváleno k publikování: 14.3.2018

\section{Úvod}

Venkovský cestovní ruch je dominantou především domácího cestovního ruchu. Jak uvádí Zhou (2014) je venkovský cestovní ruch opakem masového cestovního ruchu. Venkovský cestovní ruch je založen na propojení člověka s prrírodou, trvalé udržitelnosti a pozitivním vlivu na prrírodní prostředí. Součástí venkovského cestovního ruchu jsou subformy tohoto cestovního ruchu, jako je agroturistika, ekoturistika, cykloturistika nebo hipoturistika. Venkovský cestovní ruch má v České republice dlouhou tradici a značný význam. Přispívá $\mathrm{k}$ tvorbě nových pracovních míst, ke snížení migrace obyvatelstva do měst a ke zvýšení př́ijmů v době úpadku zemědělství. Česká republika si význam této formy uvědomuje a na základě dotací z Evropské unie v letech 2007-2013 podporovala rozvoj venkovského cestovního ruchu. V letech 20142020 je podporován z dotací prímo agroturismus (MMR 2012). Podle dat ČSÚ (2017) významně převyšuje domácí cestovní ruch rezidentů ČR nad výjezdovým. Dlouhodobých cest (4 a více přenocování) uskutečnili rezidenti České republiky 8354 000, výjezdů do zahraničí 4276000 . Hlavním důvodem domácích cest byla rekreace a odpočinek. Z $53 \%$ byly účastnicemi domácího cestovního ruchu ženy. Krátkodobých cest (1-3 přenocování) bylo realizováno 17702 000, výjezdů pouze 1276000 . Krátkodobé cesty rezidentů po ČR jsou primárně uskutečňovány za účelem návštěvy př́buzných, a i v tomto př́ípadě se na něm podílejí $\mathrm{z}$ více než 50 \% ženy.

Výzkum je zaměřen na hodnocení faktorů kvality z pohledu návštěvníků, a to z toho důvodu, že jsou to právě návštěvníci, kdo platí za služby a zboží v destinaci a jsou tak nositeli pozitivního ekonomického efektu (Lehtinen 2007). Jak uvádí Dolnicar (2008), vzhledem k heterogenitě návštěvníkủ, je potřebné využít segmentaci, aby byli seskupeni návštěvníci se stejnými požadavky. Hlavním cílem tohoto výzkumu bylo zjistit, zda je vnímání kvality venkovské destinace cestovního ruchu závislé na pohlaví. Na genderové rozdíly v rámci 
cestovního ruchu upozornili např́íklad Ryan a kol. (1998) nebo Kim a kol. (2007). Ryan a kol. (1998) hledali faktory, které rozhodují o výběru destinace pro dovolenou. Největší rozdíl byl u faktoru "nákupní možnosti v destinaci", který byl významnější pro ženy, stejně tak je pro ženy významnějším faktorem historická a kulturní atraktivita destinace. Muži naopak kladli důraz na sportovní vybavenost destinace. Vnímání tohoto faktoru sice nebylo závislé na pohlaví, ale jednalo se o jediný faktor, který byl významnější pro muže než pro ženy. Kim a kol. (2007) zjišt'ovali preference ve vyhledávání informací o cestování na internet. Z jejich výzkumu vyplynulo, že muži spíše vyhledávají informace o letu nebo vypůjčení vozu v destinaci. Ženy se zaměřují na vyhledávání informací o zábavě v destinaci a stravování.

Z výše uvedených výzkumů je zřejmé, že je problematika genderu řešena i v zahraničí a výsledky jsou významné pro další rozvoj destinací. Proto je vhodné provedení výzkumu i v rámci České republiky.

\section{Literární východiska}

V úvodu výzkumu bylo nutné definovat venkovskou destinaci cestovního ruchu, aby bylo zřejmé, jaký územní celek bude zkoumán. Její vymezení není možné přejímat z geograficky odlišných zemí. United States Census Bureau (v Ricketts 1998) definuje venkovskou destinaci jako oblast, ve které je hustota obyvatel menší než 1000 osob na čtverečnou míli, a zároveň je počet obyvatel menší než 2500 . Toto rozpětí není v podmínkách České republiky aplikovatelné. Stejně na problematiku nahlíží i Evropská komise zemědělství a rozvoj venkova (1997), která nepovažuje definování podle hustoty za relevantní ukazatel. Valentine (2001) a Murray a kol. (2008) se shodují, že v prípadě venkovské destinace by se nemělo jednat o vymezení geografické, ale spíše o definování na základě společenských hodnot a kultury daného místa. Sharpleyovi (1997) vymezují venkovskou destinaci cestovního ruchu jako místo, mimo velká města, s četnými menšími vesnicemi, které vykazují nízkou hustotu osídlení a ekonomikou založenou na zemědělství a kultuře. Kastenholz a kol. (2012) vnímají venkovskou destinaci obdobně: malé vesnice, které disponují lokální faunou a florou a dokáží uspokojit potřebu návštěvníka na využití volného času. V Lotyšsku vymezila Asociace venkovského cestovního ruchu tyto oblasti počtem obyvatel do $5000 \mathrm{~s}$ krajinou založenou na zemědělství a př́rodních hodnotách. Výchozí definicí pro výzkum bylo sloučení výše zmíněného a byly zkoumány oblasti mimo velká města, které měly do 5000 obyvatel, jejich ekonomika vycházela ze zemědělské produkce, a zároveň destinace disponovala materiálně-technickou základnou pro cestovní ruch.

Hlavním tématem výzkumu byla kvalita v cestovním ruchu, na kterou lze také nahlížet z mnoha pohledů. Podle Potočníka (2006) je to právě kvalita, na základě, které se návštěvníci rozhodují o realizaci pobytu. Žabkar a kol. (2010) vnímají kvalitu destinace, jako jeden z faktorů, které jsou nezbytné pro úspěšné fungování destinace. Světová organizace cestovního ruchu (UNWTO 2003) vymezila kvalitu v cestovním ruchu, jako splnění všech legitimních požadavků návštěvníků za přijatelnou cenu. Palatková (2006) vnímá obdobně kvalitu destinace. Kvalitní destinace je podle ní taková destinace, která dokáže splnit očekávání návštěvníka a $\mathrm{v}$ rámci konkurence nabídnout i něco navíc.

Problematika kvality v cestovním ruchu je řešena odbornou veřejností právě proto, že je složité ji obecně definovat. Hodnocení kvality je z velké míry závislé na hodnotiteli/návštěvníkovi destinace. Jak uvádí Nejdl (2011), je hodnocení kvality v cestovním ruchu závislé na věku návštěvníka, jeho životním stylu, finančních možnostech a dalších faktorech. Určitý vliv na posuzování kvality má i předešlá zkušenost návštěvníka. Ke kvalitě je proto přistupováno individuálně a je obtížné ji generalizovat. 
Jak je naznačeno výše, je hodnocení kvality závislé na mnoha faktorech. Tento výzkum se zabýval vlivem pohlaví na vnímání kvality. Existence rozdílného chování mužů a žen v rámci cestovního ruchu byla již několikrát potvrzena. Kim a kol. (2007) zjistili, že existují rozdíly mezi tím, jak muži a ženy vyhledávají informace o cestování na internetu. Collins and Tisdell (2002) odhalili existence genderového rozdílu i v rámci motivace k cestování. Uvádějí, že ženy se častěji vydávají na návštěvy prŕbuzných, muži nejčastěji vyjíždějí na pracovní cesty. Anderson a Littrell (1995) na základě svého výzkumu poukázali na fakt, že vzpomínky na cestování a nákup suvenýrů jsou dominantou ženy nikoliv mužů. Problematikou genderu ve spojitosti s destinací se zabývali např́klad Um a Crompton (1990), kteří poukázali na to, že demografické charakteristiky (mimo jiné tedy i pohlaví) ovlivňují výběr cílové destinace. Stejné téma si vybrala i Ryan a kol. (1998), která poukázala na fakt, že ideální destinace cestovního ruchu není pro muže a ženy totožná.

Prokázalo se tedy, že problematikou genderových rozdílů v rámci hodnocení faktorů kvality destinace cestovního ruchu, je potřebné se zabývat, nebot' se existence těchto rozdílů již v minulosti prokázala. Zjištění této diference může mít pozitivní dopad na marketingové řízení destinace, tvorbu produktů a další související odvětví.

\section{Metodika}

Pro účely výzkumu byl sestaven dotazník, v rámci, kterého respondenti hodnotili 23 faktorů kvality destinace na pěti stupňové škále významu, kde hodnota 1 vyjadřovala nejnižší význam faktoru a hodnota 5 význam nejvyšší. Faktory byly stanoveny na základě předešlých empirických studií, které se zabývaly kvalitou destinace jako takové (Ryglová a kol. 2015; Aldere a kol. 2011; Mussalam a Tajeddini 2016) nebo př́mo venkovské destinace (Frochot 2005).

Data byla sbírána od návštěvníků tř́i turistických regionů - Šumava, Vysočina a Jižní Morava, které byly na základě mapy, kterou vytvořil Svaz venkovské turistiky, vyhodnoceny jako oblasti s nejhustší koncentrací farem a ubytovacích zařízení. Zvolením těchto tří oblastí byla pokryta také diference mezi venkovskými oblastmi, které jsou zaměřeny na specifické formy venkovského cestovního ruchu, jako je horská turistika, vinařská turistika nebo eko a agroturistika. Konkrétní zkoumané oblasti byly vymezeny (jak již bylo výše uvedeno) následovně: oblasti mimo velká města, do 5000 obyvatel, jejichž ekonomika je založena na zemědělské produkci, a zároveň destinace disponují materiálně-technickou základnou pro cestovní ruch. Cíloví respondenti byli rezidenti České republiky starší 18 let. Respondenti mohli vyplnit dotazník velektronické podobě nebo v podobě písemné. Listinný dotazník byl $\mathrm{k}$ dispozici u vybraných poskytovatelů služeb v rámci venkovských destinací. Respondenty byly osoby, které byly v destinaci alespoň na jednodenní návštěvě. Tranzitní návštěvníci nebyli zahrnuti do výzkumu. Byl zvolen kvótní výběr, kdy kvótou bylo pohlaví respondentů.

Pro vyhodnocení dat byl využit Kruskal - Wallisův test. Jedná se o neparametrický test, který porovnává nezávislé proměnné (Budíková a kol. 2010). Testována byla hypotéza, že pohlaví nemá vliv na vnímání kvality venkovské destinace. Hypotéza byla testována na hladině významnosti $\mathrm{p}<0,05$.

\section{Výsledky výzkumu}

Zkoumaný soubor 660 respondentů, z nichž 50 \% bylo mužů a $50 \%$ žen, byl dále identifikován na základě vzdělání, věku a bydliště. Z celkových 660 respondentů mělo $2 \%$ základní vzdělání, $10 \%$ středoškolské bez maturity, 58 \% středoškolské s maturitou a $30 \%$ vysokoškolské. Nejčetnějšími skupinami z pohledu věku byli respondenti od 18 do 45 let. Jedná se tak, mimo 
jiné, především o rodiny s dětmi, které jsou, dle Ministerstva pro místní rozvoj (2008) hlavním segmentem venkovského cestovního ruchu. Z pohledu bydliště byli nejvíce zastoupeni respondenti z Jihomoravského kraje, Vysočiny a Olomouckého kraje.

Výsledky v tabulce č. 1 ukazují, že pohlaví je směrodatné ve vnímání kvality u 10 faktorů kvality: komunikace pred př́jezdem, kulturni atraktivity, aktivity související s pobytem, dostupnost informaci, dopravni infrastruktura, festivaly $v$ destinaci, prijetí místními obyvateli, kapacita destinace, mistní doprava a bezbariérový prístup. Celkově nejvyššího významu pro obě pohlaví dosáhly faktory: bezpečnost destinace $(4,2)$, čistota destinace $(4,18)$ a prírodní atraktivity $(4,17)$.

Tabulka 1: Diferenciace vnímání faktorů kvality na základě pohlaví

\begin{tabular}{|c|c|c|c|c|}
\hline Faktory kvality & Význam & Median & $\begin{array}{l}\text { Směrodatná } \\
\text { odchylka }\end{array}$ & $\begin{array}{l}\text { Kruskal - Wallis test } \\
\text { gender }\end{array}$ \\
\hline Pocit bezpečí & 4,2 & 4 & 0,96 & $\mathrm{Ne}$ \\
\hline Čistota destinace & 4,18 & 4 & 0,9 & $\mathrm{Ne}$ \\
\hline Přírodní atraktivity & 4,17 & 4 & 0,98 & $\mathrm{Ne}$ \\
\hline Komunikace před př́ijezdem & 4 & 4 & 0,97 & Ano \\
\hline $\begin{array}{l}\text { Úroveň pracovníků ve } \\
\text { službách }\end{array}$ & 3,99 & 4 & 0,9 & $\mathrm{Ne}$ \\
\hline Stravovací zařízení & 3,96 & 4 & 0,89 & $\mathrm{Ne}$ \\
\hline Kulturní atraktivity & 3,95 & 4 & 0,97 & Ano \\
\hline Ubytování & 3,91 & 4 & 0,95 & $\mathrm{Ne}$ \\
\hline Cena produktů a služeb & 3,85 & 4 & 0,93 & $\mathrm{Ne}$ \\
\hline $\begin{array}{l}\text { Aktivity související } \\
\text { s pobytem }\end{array}$ & 3,77 & 4 & 1,05 & Ano \\
\hline Dostupnost informací & 3,74 & 4 & 0,96 & Ano \\
\hline $\begin{array}{l}\text { Předchozí návštěva/pozitivní } \\
\text { reference }\end{array}$ & 3,69 & 4 & 1,02 & $\mathrm{Ne}$ \\
\hline Dopravní infrastruktura & 3,66 & 4 & 1 & Ano \\
\hline Unikátnost destinace & 3,65 & 4 & 1,01 & $\mathrm{Ne}$ \\
\hline Image destinace & 3,55 & 4 & 0,96 & $\mathrm{Ne}$ \\
\hline Festivaly v destinaci & 3,46 & 4 & 1,07 & Ano \\
\hline Trvalá udržitelnost destinace & 3,46 & 4 & 0,97 & $\mathrm{Ne}$ \\
\hline Doplňková infrastruktura & 3,42 & 3 & 1 & $\mathrm{Ne}$ \\
\hline Přijetí místními obyvateli & 3,41 & 3 & 1,05 & Ano \\
\hline Kapacita destinace & 3,35 & 3 & 0,99 & Ano \\
\hline Místní doprava & 3,1 & 3 & 1,13 & Ano \\
\hline Vzdálenost od domova & 2,81 & 3 & 1,18 & $\mathrm{Ne}$ \\
\hline Bezbariérový prístup & 2,78 & 3 & 1,24 & Ano \\
\hline
\end{tabular}

Zdroj: Autoři 
Význam jednotlivých faktorů kvality byl pro muže a ženy odlišný, jak naznačuje tabulka č. 2. Všechny faktory kvality destinace byly ženami hodnoceny, z pohledu významu, výše než muži. $\mathrm{V}$ prvních třech nejvýznamnějších faktorech došlo u obou pohlaví ke shodě. Jedná se o pocit bezpečí, čistotu destinace a př́rodni atraktivity. Dále se již výsledky rozcházejí. Pro ženy jsou dalšími významnými faktory kvality komunikace před příjezdem a kulturní atraktivity. Muži hodnotili jako významnější úroveň pracovníků ve službách a stravovací zařízení.

Tabulka 2: Význam faktorů pro jednotlivá pohlaví

\begin{tabular}{|c|c|c|}
\hline Faktory kvality & $\begin{array}{l}\text { Význam pro ženy } \\
\text { - aritm. průměr }\end{array}$ & $\begin{array}{l}\text { Význam pro muže - } \\
\text { aritm. průměr }\end{array}$ \\
\hline Pocit bezpečí & 4,27 & 4,13 \\
\hline Čistota destinace & 4,27 & 4,1 \\
\hline Přírodní atraktivity & 4,23 & 4,12 \\
\hline Komunikace před př́ijezdem & 4,11 & 3,88 \\
\hline Kulturní atraktivity & 4,07 & 3,82 \\
\hline Úroveň pracovníků ve službách & 4,02 & 3,96 \\
\hline Stravovací zařízení & 4 & 3,91 \\
\hline Ubytování & 3,93 & 3,89 \\
\hline Cena produktů a služeb & 3,89 & 3,8 \\
\hline Aktivity související s pobytem & 3,85 & 3,7 \\
\hline Dostupnost destinace & 3,84 & 3,63 \\
\hline $\begin{array}{l}\text { Předchozí návštěva/pozitivní ref- } \\
\text { erence }\end{array}$ & 3,76 & 3,62 \\
\hline Dopravní infrastruktura & 3,75 & 3,56 \\
\hline Unikátnost destinace & 3,69 & 3,6 \\
\hline Image destinace & 3,61 & 3,49 \\
\hline Festivaly v destinaci & 3,55 & 3,37 \\
\hline Trvalá udržitelnost destinace & 3,53 & 3,39 \\
\hline Přijetí místními obyvateli & 3,51 & 3,31 \\
\hline Doplňková infrastruktura & 3,49 & 3,34 \\
\hline Kapacita destinace & 3,47 & 3,22 \\
\hline Místní doprava & 3,22 & 2,97 \\
\hline Bezbariérový př́istup & 2,88 & 2,68 \\
\hline Vzálenost od bydliště & 2,86 & 2,76 \\
\hline
\end{tabular}

Zdroj: Autoři

\section{Diskuze}

Vzhledem k velkému množství venkovských destinací cestovního ruchu v České republice, jsou tyto destinace vzájemně snadno substituovatelné. Kvalita tak může být jeden z rozhodujících faktorů, které ovlivní rozhodnutí návštěvníka. Autorky se v rámci výzkumu 
zabývaly rozdíly mezi vnímáním faktorů kvality jednotlivými pohlavími. Výzkum, který probíhal výhradně v České republice a byl zaměřený na její rezidenty, prokázal rozdíly ve vnímání faktorů kvality, a to konkrétně u 10 z 23 testovaných faktorů.

Nejvýznamnějším faktorem, který vnímají obě pohlaví stejně, byla bezpečnost. Je to právě bezpečnost, na které závisí výběr destinace návštěvníkem (Fuchs a Pizam 2011 v Wang a Pizam 2011). Při výběru destinace má tento faktor největší sílu ovlivnit návštěvníkovo rozhodnutí. Dwyer (Dwyer 2009 v Wang a Pizam 2011) očekával v roce 2009, že v následujících 15 letech bude pokračovat trend, kdy bude cestovní ruch ovlivňován především terorismem nebo infekčními nemocemi. Vzhledem $\mathrm{k}$ tomu, že tímto negativním způsobem byl ovlivněn především cestovní ruch mimo Českou republiku a současně je Česká republika považována podle GPI (2017) za 6. nejbezpečnější zemi, lze zde předpokládat nárůst nejen domácího cestovního ruchu. Na základě toho lze považovat venkovský cestovní ruch za jednu z perspektivních forem cestovního ruchu v České republice.

Mezi faktory, v jejichž vnímání hraje rozdíl pohlaví, patří například komunikace před př́jezdem. Podle studie Jucanových (2013) ženy kladou důraz na komunikaci s personálem a sociální kontakt je velmi ovlivňuje. Totožný výsledek poskytl i tento výzkum v rámci venkovské destinace. Rozdíl byl potvrzen i u faktorů bezbariérový přistup a dopravní infrastruktura. Jak uvádí OSN (2017) přístupnost v cestovním ruchu není jen o lidech $\mathrm{s}$ hendikepem, ale i o seniorech nebo těhotných ženách. Dopravní dostupnost $\mathrm{s}$ tímto úzce souvisí. Mezinárodní fórum dopravy (2011) sice konstatuje, že není dostatek statistik, aby mohly být genderové rozdíly kvalitně posouzeny, ale je evidentní, že je menší počet žen, které by měly vlastní osobní automobil než mužů. Proto pro ně může být zásadnější i rozvinutí dopravní infrastruktury v rámci cestovního ruchu.

Výsledky výzkumu lze komparovat s výsledky studie Rašovské a kol. (2016), která je zaměřena na faktory kvality městské destinace. Respondenty byly $\mathrm{v}$ obou př́padech rezidenti České republiky. Pro respondenty, kteří navštívili venkovskou destinaci, jsou nejvýznamnějšími faktory kvality pocit bezpeči $(4,2)$, čistota destinace $(4,18)$ a př́rodní atraktivity $(4,17)$. V rámci městské destinace byly nejvýznamnějšími faktory zvoleny kulturní atraktivity $(3,94)$, pocit bezpečí $(3,86)$ a čistota destinace $(3,84)$. At’ už se jedná o návštěvníky jakékoliv destinace, je patrné, že bezpečnost a čistota destinace jsou významnými faktory kvality. Faktory př́rodních a kulturních atraktivit pak př́mo korespondují s typem destinace. Pro městský typ destinace je typickou formou cestovního ruchu kulturně - poznávací cestovní ruch. Ve venkovských oblastech se jedná o formy, jako jsou agroturistika, cykloturistika nebo vinařská turistika, které jsou úzce spjaty s prŕrodními atraktivitami (Pásková 2003 v Vystoupil a kol. 2007).

Mezi omezení výzkumu jednoznačně patři šíře výstupu. Dále by měly být odhaleny rozdíly ve vnímání kvality destinace u jednotlivých věkových struktur. V rámci výzkumu byly zkoumány tři turistické regiony, které by měly být testovány samostatně, aby byl vyloučen vliv destinací na genderové hodnocení. Pro toto zkoumání by bylo vhodné mít sesbíraný větší objem dat, která by měla větší vypovídací schopnost. Limitem pro diskuzi je malé množství výzkumů, které by reflektovaly tuto problematiku. Není tak možná relevantní diskuze.

\section{Závěr}

Výstupy výzkumu, které potvrdily u 10 z 23 faktorů kvality odlišné genderové vnímání, by mohly pomoci managementu a marketingu destinací. Destinační managementy vytvářejí programové balíčky služeb, ve kterých by mohly být reflektovány požadavky jednotlivých pohlaví. Pro ženy by byly vytvářeny balíčky zaměřené na kulturní atraktivity, pro muže 
s gastronomickým kontextem. Kvalitu komunikace před př́jezdem a úroveň jednotlivých pracovníků ve službách lze také prezentovat. V rámci webové prezentace lze např́klad uvést časový údaj, do kdy poskytovatel služby bude reagovat na dotazy klienta. Úroveň pracovníků ve službách lze komunikovat veřejnosti formou prezentace získaných certifikátů a osvědčení. Všechna doporučení jsou zaměřena na online komunikaci, nebot' propagační materiály v papírové formě poskytují pouze základní informace. Tato doporučení může aplikovat destinační management i samotný poskytovatel služeb v rámci webové prezentace. Destinační management může být dále tvůrcem kvalifikačních kurzů, které budou zaměřeny na rozvoj pracovníků ve službách.

Vzhledem k vývoji cestovního ruchu mají venkovské destinace růstový potenciál a je jen na nich, jak se dokáží na trhu cestovního ruchu prosadit. Faktory kvality jsou na prvních třech místech pro obě pohlaví shodná, v těchto prrípadech je možné volit jednotnou marketingovou komunikaci, která by kladla důraz na tyto faktory. Bezpečnost destinace je propagována především marketingovou agenturou CzechTourism, a to primárně v materiálech, které jsou určené odborné veřejnosti. Potenciálním návštěvníkům tyto informace nejsou interpretovány. Destinační managementy zkoumaných oblastí reflektují ve svých propagačních materiálech a webových prezentacích primárně prrírodní atraktivity. Skrze správnou prezentaci prírodních atraktivit lze také navodit v potenciálním návštěvníkovi pocit bezpečné a čisté destinace. Mendelsohn (Mendelsohn 2016 v Fortune.com, autorka: Claire Zillman (2016) uvedla, že budoucnost bude o komunikaci skrze video nikoliv text, protože je to nejlepší nástroj $\mathrm{k}$ vyprávění př́běhů. $\mathrm{V}$ cestovním ruchu byly $\mathrm{v}$ minulosti využívány časosběrná videa. Aktuálním trendem, který by měly destinační managementy využívat, je virtuální realita a $360^{\circ}$ videa.

Kvalita destinace může být pro destinaci konkurenční výhodou, která ji odliší od ostatních. Výsledky výzkumu tak mohou pomoci destinačním managementům a poskytovatelům služeb k dosažení vyšší úrovně kvality.

\section{Poděkování}

Výzkum byl zpracován a financován na základě projektu IGA 2017009, Mendelovy univerzity v Brně.

\section{Literatura}

[1] ALDERE, J. et al., 2011. Analyzing the influence of tourist motivations on tourist exenditure at a sun-and-sand destination. Tourism Economics, 17(4), 813-832.

[2] ANDERSON, L. F. and M. A. LITTRELL, 1995. Souvenir-purchase behaviour of women tourists. Annals of Tourism Research, 22(2), 328-348.

[3] BUDÍKOVÁ, M. a kol., 2010. Prưvodce základními statistickými metodami. Praha: Grada Publishing. ISBN 978-80-247-3243-5.

[4] Cestovní ruch pro všechny [online]. Praha: Ministerstvo pro místní rozvoj ČR, 2008 [cit. 2017-11-16].

ISBN

978-80-7399-407-05.

Dostupné

$\mathrm{z}$ : https://www.mmr.cz/getmedia/4fa1846e-ee0c-40d7-ae2e-a43007314a2e/GetFile14_1.pdf

[5] COLLINS, D. and C. TISDELL, 2002. Gender and Differences in Travel Life Cycles. Journal of Travel Research, 41(2), 133-143. DOI: 10.1177/004728702237413. ISSN 0047-2875. 
[6] Český statistický úřad: Cestovní ruch - časové řady. Český statistický úřad [online]. Praha, 2017 [cit. 2017-12-04]. Dostupné z: https://www.czso.cz/csu/czso/cru_cr

[7] DOLNICAR, S., 2008. Market segmentation in tourism, in Woodside, AG and Martin, D (eds), Tourism Management: Analysis, Behaviour and Strategy, CAB International, Cambridge, 129-150.

[8] European Commission. Rural developments: CAP 2000 Working document. European Commission EU, Directorate General for Agriculture, 1997, 78.

[9] FROCHOT, I., 2005. A benefit segmentation of tourists in rural areas: a Scottish perspective. Tourism Management, 26(3), 335-346.

[10] International Transport Forum: Gender and Transport [online]. Francie, 2011 [cit. $2017-$ 11-25]. Dostupné z: https://www.itf-oecd.org/sites/default/files/docs/dp201111.pdf

[11] JUCAN, S. M. and C. N. JUCAN, 2013. Gender Trends in Tourism Destination. Procedia - Social and Behavioral Sciences[online].92, 437-444 [cit. 2017-12-04]. DOI: 10.1016/j.sbspro.2013.08.698. ISSN 18770428.

[12] KASTENHOLZ, E. et al., 2012. Understanding and managing the rural tourism experience - The case of a historical village in Portugal. Tourism Management Perspectives, 4, 207-214. DOI: 10.1016/j.tmp.2012.08.009. ISSN 22119736.

[13] KIM, D. et al., 2007. Gender differences in online travel information search: Implications for marketing communications on the internet. Tourism Management, 28(2), 423433. DOI: 10.1016/j.tourman.2006.04.001. ISSN 02615177.

[14] Lauku celotajs: Baltic Country Holidays - Rural tourism definition [online]. Lotyšsko [cit. 2017-11-14]. Dostupné z: http://www.celotajs.lv/cont/prof/assoc/definition_en.html

[15] LEHTINEN, J. Aktivní CRM: řizení vztahů se zákazníky. 1. vyd. Praha: Grada, 2007, 158. ISBN 978-80-247-1814-9.

[16] Ministerstvo pro místní rozvoj [online]. Praha, C2012 [cit. 2017-09-25]. Dostupné z: http://www.mmr.cz/cs/Regionalni-politika-a-cestovni-ruch/Cestovni-ruch/ProgramyDotace

[17] MURRAY, A. G. et al., 2008. Scaling the Rural: Reflections on Rural Cultural Studies. Australian Humanities Review. 45, 37 - 52. ISSN 1325-8338.

[18] MUSSALAM, G. Q. and K.TAJEDDINI, 2016. Tourism in Switzerland: How perceptions of place attributes for short and long holiday can influence destination choice. Journal of Hospitality and Tourism Management, 26, 18-26. DOI: 10.1016/j.jhtm.2015.09.003. ISSN 14476770.

[19] NEJDL, K. Management destinace cestovního ruchu. Vyd. 1. Praha: Wolters Kluwer Česká republika, 2011. ISBN 978-80-7357-673-8.

[20] PALATKOVÁ, M., 2006. Marketingová strategie destinace cestovního ruchu: jak získat vice př́jmi̊ z cestovního ruchu. Praha: Grada. ISBN 80-247-1014-5.

[21] POTOČNIK, M., 2006. Multi-attribute model for the assessment of farm tourism's supply quality. Unpublished master's thesis, University of Maribor, Maribor, Slovenia.

[22] Prázdniny na venkově [online]. Telč [cit. 2017-11-14]. Dostupné z: http://www.prazdninynavenkove.cz/

[23] RAŠOVSKÁ, I. et al., 2016. The dimensions and quality factors in urban destinations. Czech Hospitality and Tourism Papers, 27(7), 19-27. ISSN: 1801-1535. 
[24] RICKETTS, T. C., K. D. JOHNSON-WEBB and P. TAYLOR, 1998. Definitions of Rural:

A Handbook for Health Policy Makers and Researchers. University of North Carolina at Chapel Hill

[25] RYAN, M. et al., 1998. Gender differences in tourism destination choice: Implications for tourism marketers, Australian and New Zealand Marketing Conference, Dunedin, New Zealand, 1998, 2306 - 2317.

[26] RYGLOVÁ, K. et al., 2015. The Quality as a Competitive Factor of the Destination. Procedia Economics and Finance, 34, 550-556. DOI: 10.1016/S2212-5671(15)01667-6. ISSN 22125671.

[27] SHARPLEY, S. and J. SHARPLEY, 1997. Rural Tourism: An Introduction. London: International Thomson Business Press, 165. ISBN 978-04-151-4010-2.

[28] UM, S. and J. L. CROMPTON, 1990. Attitude determinants in tourism destination choice. Annals of Tourism Research, 17(3), 432-448.

[29] United Nations: Promoting accessible tourism for all [online]. 2017 [cit. 2017-11-25]. Dostupné z: https://www.un.org/development/desa/disabilities/issues/promotingaccessible-tourism-for-all.html

[30] UNWTO Quality Support Committee. Quality in Tourism, UNWTO Quality Support Committee 6th meeting, Varadero, Cuba. 2003, [cit. 2016-04-06]. Dostupné z: http://sdt.unwto.org/en/content/quality-tourism.

[31] VALENTNE, G., 2001. Social Geographies: Space and Society. New York: Prentice Hall.

[32] Vision of Humanity: Global Peace Index 2017 [online]. The Institute for Economics and Peace, (C2017 [cit. 2017-11-16]. Dostupné z: http://visionofhumanity.org/indexes/globalpeace-index/

[33] VYSTOUPIL, J. a kol., 2007. Vymezováni destinace a formulace jejích charakteristik a organizace cestovního ruchu $v$ destinaci [online]. Praha: Ministerstvo pro místní rozvoj ČR, [cit. 2017-11-25]. Dostupné z: https://www.mmr.cz/getmedia/656473c9-3527-4007aafd-b09f029ea418/GetFile2_3.pdf

[34] WANG, Y. and A. PIZAM, 2011. Destination marketing and management: theories and applications. Cambridge, MA: CABI. ISBN 9781845937621.

[35] ZHOU, L., 2014. Online rural destination images: Tourism and rurality. Journal of Destination Marketing \& Management, 3(4), 227 - 240. DOI: 10.1016/j.jdmm.2014.03.002. ISSN 2212571x.

[36] ZILLMANN, C., 2016. Fortune: Why Facebook Could Be 'All Video' in 5 Years [online]. [cit. 2017-12-03]. Dostupné z: http://fortune.com/2016/06/14/facebook-video-live/

[37] ŽABKAR, V. et al., 2010. Modelling perceived quality, visitor satisfaction and behavioural intentions at the destination level. Tourism Management [online], 31(4), 537546 [cit. 2017-12-04]. DOI: 10.1016/j.tourman.2009.06.005. ISSN 02615177. 